\section{Resilience to Sudden Climate Change: The Impact of the Bromo 2010 Volcanic Ash Eruption on the Growth of Chillies}

\section{Arry Y Nurhayati ${ }^{\mathrm{a}^{*}}$, Yuda C Hariadi ${ }^{\mathrm{a}}$, A Sholihin $^{\mathrm{a}}$}

a) Physics Department Faculty of Mathematics and Natural Sciences University of Jember, Jember 68121, East Java, Indonesia

Received: October 11, 2015/ Accepted: July 05, 2017

\section{Abstract}

In the last five years, Indonesia has seen five volcanic eruptions wreak havoc on agricultural production. Our research analyzed the effects of ash from Mt Bromo's November 2010 eruption on chilli growth. Different soil composition variables, including volcanic ash taken from Bromo, produced measurable changes in aspects of plant morphology when observed inside a greenhouse. Results were collected on a weekly basis by measuring bioelectricity, plant height, number of leaves per plant and average leaf areas.

These data show that adding a proportion of one third ash into the soil makeup, enhanced growth. While, an addition of more than two- thirds ash, tended to inhibit plant growth. A proactive strategy used from this finding, could help farmers recoup their losses from the potentially negative impact of volcanic ash on their livelihoods. These tactics could be cost-effective ways to ameliorate some damage from climate change and natural disasters; even lessening a few aspects of food insecurity. In spite of results that showed that the composition of $\mathrm{Pb}, \mathrm{Cd}$ and other metals such as $\mathrm{Al}, \mathrm{Fe}$, and $\mathrm{Cu}$ on the samples, were below threshold levels, we still felt that it was important to raise awareness about the potential presence of heavy metals such as $\mathrm{Pb}$ and $\mathrm{Cd}$ in the soil.

Keywords: resilience; Bromo volcanic ash; chilli.

\begin{tabular}{|lll|}
\hline Abbreviations: \\
\hline $\mathrm{Al}$ & $:$ & Aluminum \\
$\mathrm{Mg}$ & $:$ & Magnesium \\
$\mathrm{Si}$ & $:$ & Silicon \\
$\mathrm{Fe}$ & $:$ & Iron \\
$\mathrm{Cu}$ & $:$ & Copper \\
$\mathrm{Cd}$ & $:$ & Cadmium \\
$\mathrm{Co}$ & $:$ & Cobalt \\
$\mathrm{Cr}$ & $:$ & Chromium \\
$\mathrm{Pb}$ & $:$ & Lead \\
$\mathrm{Mn}$ & $:$ & Mangan \\
$\mathrm{Ni}$ & $:$ & Nickel \\
$\mathrm{Zn}$ & $:$ & Zinc \\
$\mathrm{BVA}$ & $:$ & Bromo Volcanic Ash \\
$\mathrm{PD}$ & $:$ & Potential Difference \\
\hline
\end{tabular}

S.e : Standard error

IPPC : Intergovernmental Panel on Climate Change

\section{Introduction}

Volcanic eruptions in Indonesia during the past five years have led to social crises. Mounts Merapi, Bromo, Kelud and Sinabung all erupted between 2010-2014 (Figure 1). While Sinabung and Raung erupted during 2015 (Figure 2). It is critical for Indonesia to develop an integrated system to enable domestic preparedness and to foster resilient community building. Its development is necessary to lessen collateral damage to the Indonesian population from the continuing threat of volcanic eruptions throughout all regions.

Volcanic eruptions are significant natural disasters and drivers of climate change $[1,2]$ and pollution [3]. Besides emitting various types of greenhouse gases, volcanic eruptions also belch huge quantities of solid particles of ash [4] Cole-Dai, 2010), that might contain poisonous, heavy metals. Studying volcanic activity may increase our understanding of global warming projections [1] and may help build society's resilience to the sudden environmental changes during and after volcanic eruptions. Frequent volcanic explosions such as those in Indonesia, have permitted opportunities to compare volcanic eruptions and climate change, and thereby formulate a climate model [2]. However, since volcanic activity is local, studies depend on the recorded data collected on location. Direct investigation of the deposits could benefit the farmers exposed to Bromo volcanic ash and others in similar cases, as in the eruption in the late fall of 2010. This research was aimed at masterminding an intelligent way for farmers to use volcanic ash fallout to promote chilli growth.

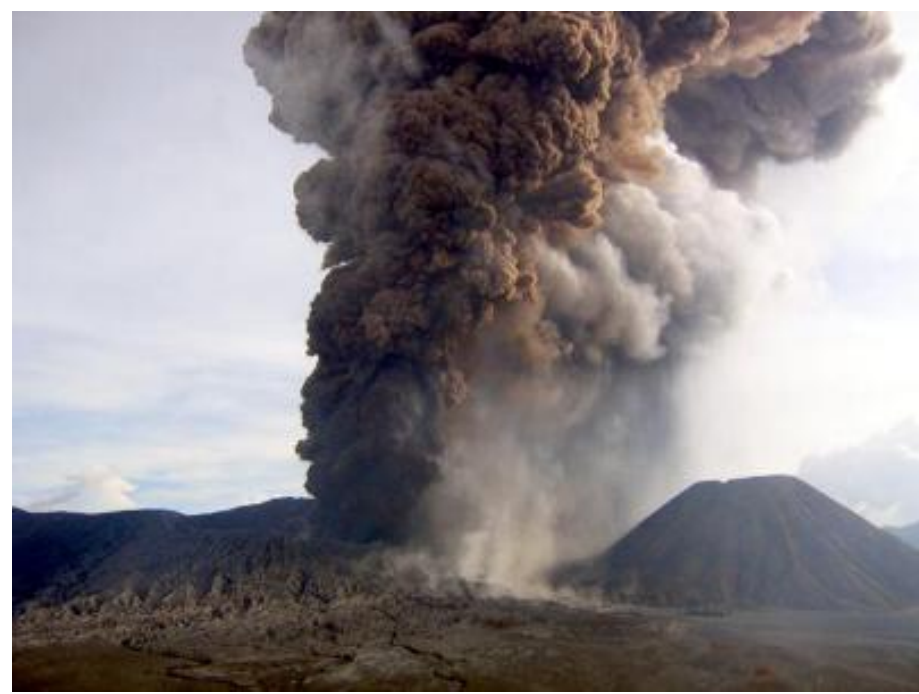

Figure 1 Bromo eruption in 2010, in East Java Indonesia. Frequent activity began in late November 2010. A long eruption that had been observed from the $29^{\text {th }}$ of January 2011, continued for nine months.

* Corresponding Author

Tel.: +62-81234-65113; Fax.: $\quad+62-331-330225$; E-mail: arrynurhayati@gmail.com 
Chilli commodities became scarce after crops were severely affected by both the Bromo eruption in 2010, [5] and the Merapi eruption in 2006, [6] thereby causing chilli prices to sky-rocket. Investigation into the effects of ash on chilli could help to foster resilience during future volcanic eruptions. Through proper management, it could be possible reduce risks by preventing social and economic crises and even support sustainability. Farmers often resumed their agricultural activity right after an eruption, mostly due to financial need (Figure 3). The uncertainty of when volcanic activity would cease, often caused stress to the displaced people. Budget constraints prevent developing countries from being able to protect their own people, and from being able to provide much needed infrastructural repair and agricultural rebuilding. Around 3 billion farmers live around mountains and rural areas with wages of 2 USD /day.

Newly reclaimed soil (Figure 3) exhibits low productivity, a lack of germination due to the toxic aluminum content, and a low concentration of nutrients $[7,6]$. High fluorine levels create risks for humans and animals exposed to them [8]. It is still undeniable that volcanic soil is a good medium for plants [9] and proper management of volcanic ash and soil could promote high productivity and long-term agricultural and environmental sustainability [10].

Volcanic ash is a pyroclastic material; a very small particle that floats in the atmosphere and may spread over very large distances. It is ejected during an eruption and its contents may differ between locations such as Bromo in Indonesia [11]; Merapi also in Indonesia [14, 6], Efjafjallajökull, in Iceland [12, 13;] and Mt. Pinatubo, in the Philippines [15]. Merapi ash samples contained aluminum (Al), magnesium $(\mathrm{Mg})$, silicon $(\mathrm{Si})$, and iron $(\mathrm{Fe})$ [14]. Pyroclastic materials [12] float on the wind, and cover a wide distance before landing on the ground. The normal composition of heavy metals found in volcanic ash are: $0.5 \mathrm{Cd}$ (cadmium), 1.4, $\mathrm{Co}$ (cobalt), $4 \mathrm{Cu}$ (copper), $3.9 \mathrm{Cr}$ (chromium), $0.03 \mathrm{Hg}$ (mercury), Mn (manganese), 3.8 Ni (nickel), 6.4 Pb (lead), and 1o $\mathrm{Zn}$ (zinc) x 10 tons per year [8].

Mount Bromo is one of the many active volcanoes in Java. It is located in Bromo-Tengger-Semeru National Park, in Probolinggo. Its highest point is $3676 \mathrm{~m}$ above sea level [16]. The Bromo eruption in 2010 was categorized as a long eruption. It began in late November, 2010. More frequent activity had been observed from the 19th January, 2011 that continued for nine months (Fig.1). From November 2010 to February 2011, the fallen ash had reached Probolinggo, Malang, Pasuruan, Lumajang, Bondowoso, Jember and Situbondo. Volcanic ash caused significant damage to agriculture and land [17]. It destroyed potato crops in Pasuruan [18] and chilli crops that were due for harvest in the Probolinggo district [5]. Society's recovery is important for cultivation. Information could have been adapted and used in other situations such as in the Kelud eruption of February 2014. Ash from this eruption flew as far as Kediri and Blitar. Ash from the Raung eruption in 2015 flew to Jember, around $100 \mathrm{~km}$ away.

People living near Mt Bromo and its surrounding areas, need resiliency; a means to adapt to sudden climate change caused by an eruption. By being prepared, farmers might be able to minimize their recovery time from natural disasters.

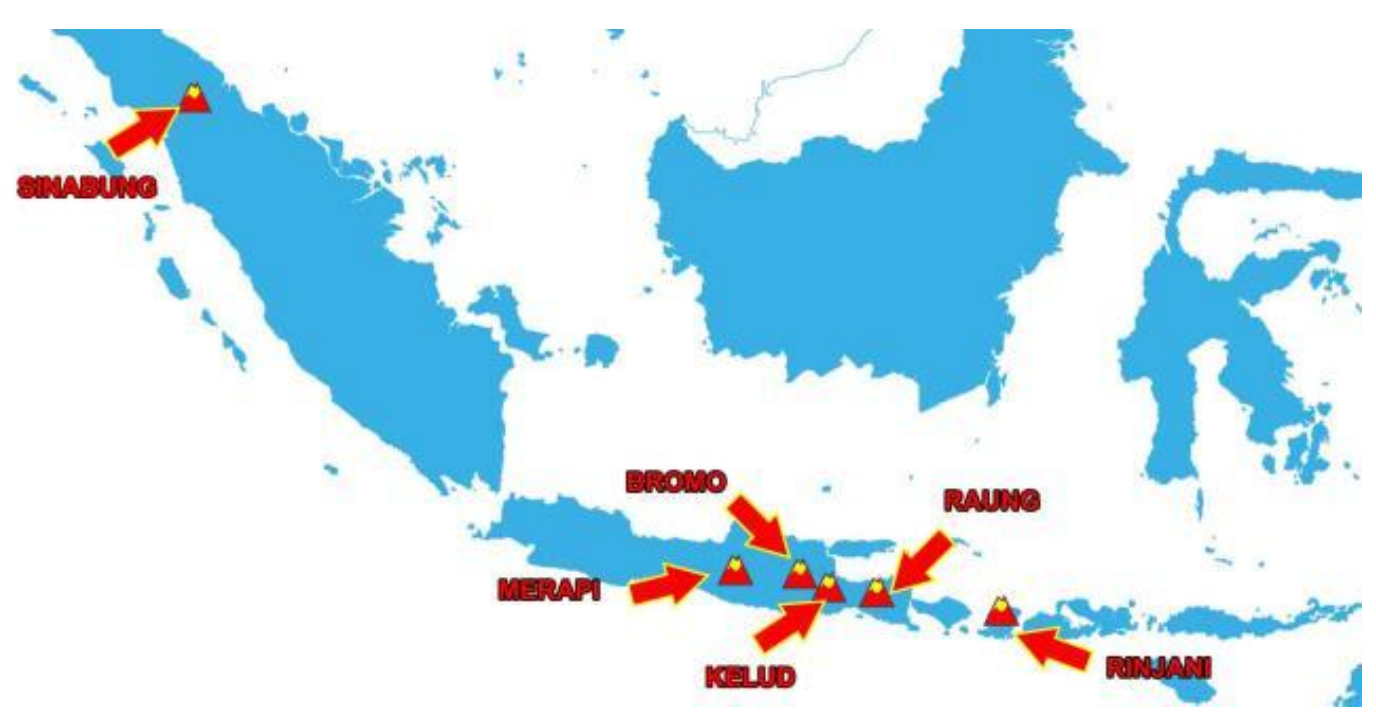

Figure 2 Five volcanoes that had erupted during 2010-2015, i.e. Mount Merapi, Bromo, Kelud (in Java Island) and Sinabung (in Sumatra Island) between 2010-2014, and Sinabung and Raung (in Java Island) during 2015 

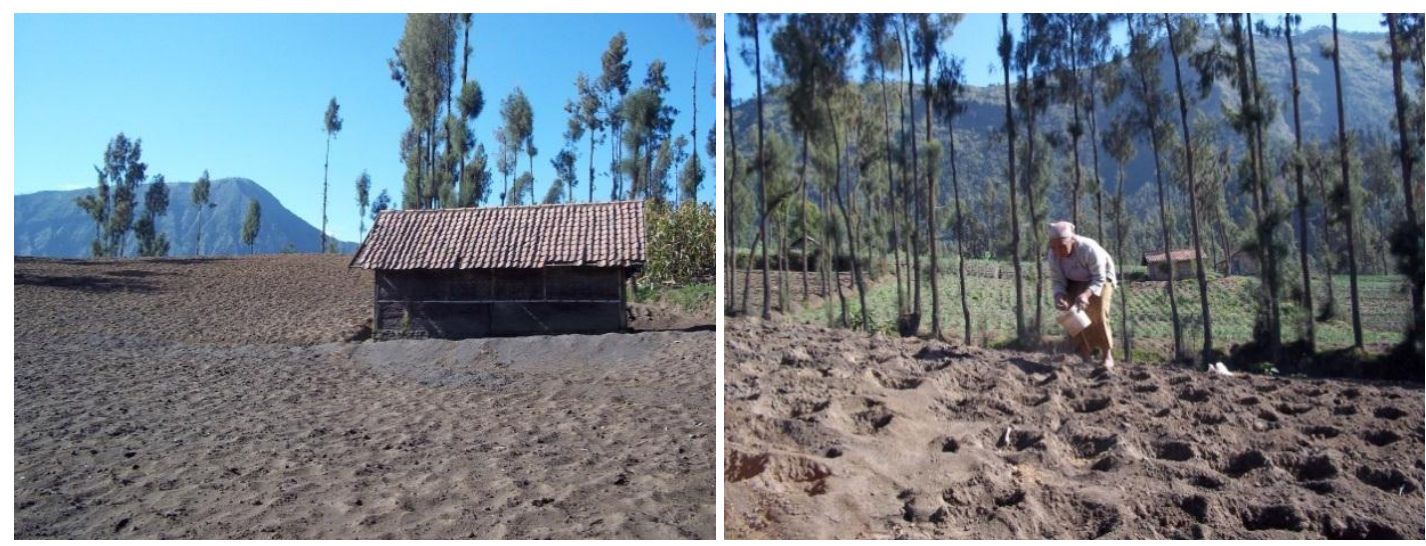

Figure 3 Ash covering a neighborhood area during the Bromo eruption in 2010 East Java Indonesia (a); and (b) a farmer starting to manage their land for farming after the Bromo eruption.

\subsection{Resilience and sustainability}

Resilience is the capability to adapt to stress [19]. The concept of resilience involving the system, community or individuals dealing with disruption, stress or shock, or sudden changes, describes an ability to anticipate, adapt and/or recover from the effects in a timely, effective manner. Preservation, renewal and enhancement of its essential basic structures and functions are included in this definition $[20,21,19]$. How people and communities respond to, manage and reorganize ways to deal with stress are no simple matters. In the case of volcanic eruptions, stress could have longterm effects. Events may recur, even while people are still recovering, and victims may be thrust into even more vulnerable positions.

In the case of Bromo, understanding the impact of volcanic ash, adapting to new conditions and developing habits to tackle the sudden changes are part of developing resilience. Reducing stress might be achieved by proper management of volcanic ash on agricultural sites. Maintaining an environmentally sustainable production of agricultural plants such as chilli is critical for the well-being of the people and for the growth of a viable economy.

By learning about the adverse effects of volcanic fallout, the information might be used to strengthen farmers under similar conditions in surrounding areas and might assist them to build their resilience. Java, Sumatra and other islands in Indonesia are areas with frequent eruptions present in Figure 2.

\section{Material and Methods \\ 2.1 The 2010 Bromo volcanic ash collection}

The term Bromo Volcanic Ash (BVA) describes ash with a tephra structure, containing pyroclastic material, including volcanic ash [7]. Bromo first erupted on 31 November, 2010 during its 2010-2011 eruption phase.

The ash samples were collected twice. Sample-1 was collected first, in between eruptions, on 17 May, 2011 between the hours of 10.00-13.0o, around five minutes after touching the ground. A long eruption marked as sample-2, and sample-3 and $112^{\circ} 58^{\prime} 53.7^{\prime \prime}$ E);

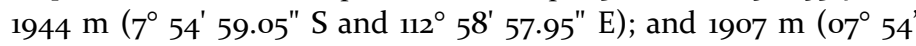
$56.3^{\prime \prime} \mathrm{E}$ and $112^{\circ} 59^{\prime} 13.7^{\prime \prime} \mathrm{E}$ ) (Figure 4). The medium for growth used debris with a thickness of $50 \mathrm{~cm}$, collected from the Ngadirejo Village, Sukopura, sub- district, Probolinggo district. The samples were collected from an altitude of $1640 \mathrm{~m}$, positioned at $7^{\circ} 55^{\prime} 39.91^{\prime \prime} \mathrm{S}$ and $113 \mathrm{o}^{\prime} 13.82$ " E, collected and transported to the university (with a total of around 1 ton). The ash was then stored and covered inside plastic containers for later use. The composition of volcanic ash was measured for its heavy metal content such as $\mathrm{Pb}, \mathrm{Cd}, \mathrm{Al}, \mathrm{Cu}$ and $\mathrm{Fe}$; for its $\mathrm{pH}$ and for its conductivity. 


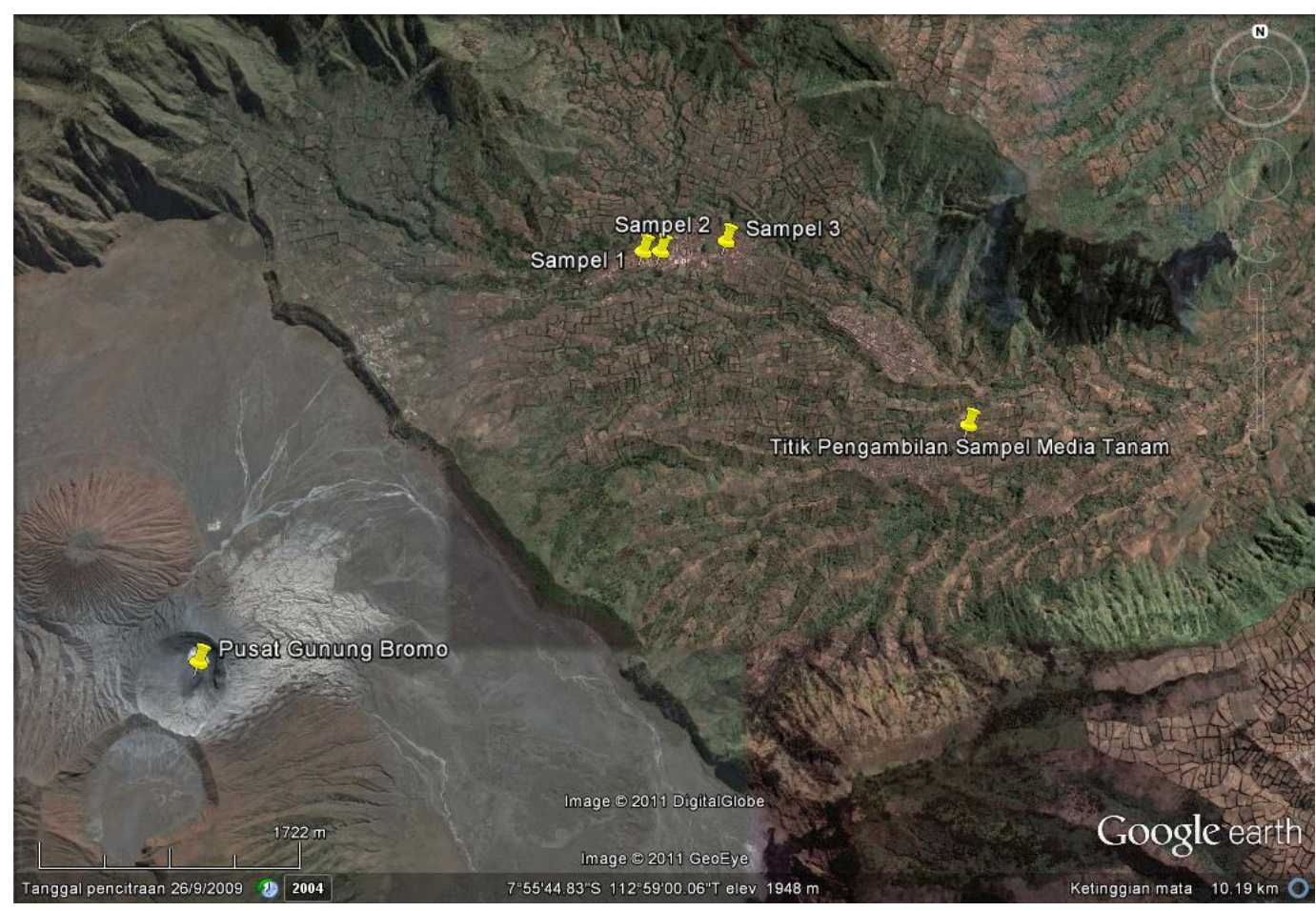

Figure 4 Mt. Bromo, Indonesia's eruption during 2010 (Google earth). Yellow points mark the source of the samples (sample 1 to 3 ) with sample-4 taken from the center of the mountain

\subsection{Plant growth and measurement}

Homogenous chilli seedlings of the Ceplik variety were cultivated in a soil growth medium purchased from a nursery shop. Healthy and homogeneous seedlings were selected and replanted in plastic pots with different mixtures of soil and Bromo volcanic (BV) ash with $100 \%$ of soil as a control, $20 \%, 33 \%, 50 \%, 67 \%$ and $80 \%$ of BV ash ratios to soil, that was then grown in a greenhouse, under randomized designs. Each treatment was replicated 5 times with 4 plants for every pot for statistical purposes.

The plant growth was observed weekly, by measuring the leaf area, the plant's height, and by observing for visual changes. A bioelectricity measurement was conducted as in [22], in line with the physiological measurement. All bioelectricity measurements were conducted in a Faraday cage in a room with controlled temperature. The results were confirmed with physiological measurements. ANOVA was used with an acceptance at $\mathrm{p}<0.05$.

\section{Results and Discussion}

\subsection{The 2010 Bromo volcanic ash effect on chilli growth}

Bromo volcanic ash influenced the growth of chilli. An addition of $20 \%$ and $33 \%$ of Bromo volcanic ash to the soil triggered the growth of the chilli variety, Ceplik (Figure 5), whereas increasing the composition of BV ash to $67 \%$ and $80 \%$ caused a reduction of growth, by reducing the height (Figure 6), average number of leaves per plant (Figure 7) and average total leaf area per plant (Figure 8). Chilli plant height was around (37.90 \pm 1.74$) \mathrm{cm}$ during the first week of measurement, at (nine weeks old), in normal soil. An addition of $33 \%$ Bromo volcanic ash to the soil increased its height to $(56.20 \pm 2.73) \mathrm{cm}$ and had reached $(58.60 \pm 2.73) \mathrm{cm}$ during the $4^{\text {th }}$ week of measurement at (12 weeks old) compared to its normal growth of $(43.90 \pm 1.74) \mathrm{cm}$ (Figure. 6).

The significant effect of $33 \% \mathrm{BV}$ ash was also observed by the numbers of leaves per plant, $139 \pm 8$ compared to its normal $98 \pm 4$ (Figure. 7). The average total leaf area per plant was (1867.00 \pm $209.48) \mathrm{cm}^{2}$ as compared to its normal growth $(548.04 \pm 27.55) \mathrm{cm}^{2}$ (Figure 8$)$. While a (50:50) \% BV ash to soil composition seemed to disrupt the growth of chilli plant more during earlier growth (Figure 5) to maturity (Figure 10) with growth retardation (Figure 5) and smaller average total leaf area (Figure 8), late flowering, fruit ripening and lesser fruit numbers (Figure 10).

An addition of $33 \%$ BV ash had promoted optimal growth. Even though a BV ash addition greater than $50 \%$ had less growth than chilli grown under $50 \%$ of $\mathrm{BV}$ ash, there was still an increase in height for every week during week 1 to week 4 (Figure 6), while the total leaf area and leaves per plant had both decreased (with an exception to $50 \%$ of BV ash treatment) on week-4 (Figure 8). The measurement was done from $9^{\text {th }}$ week to the $12^{\text {th }}$ week after planting 


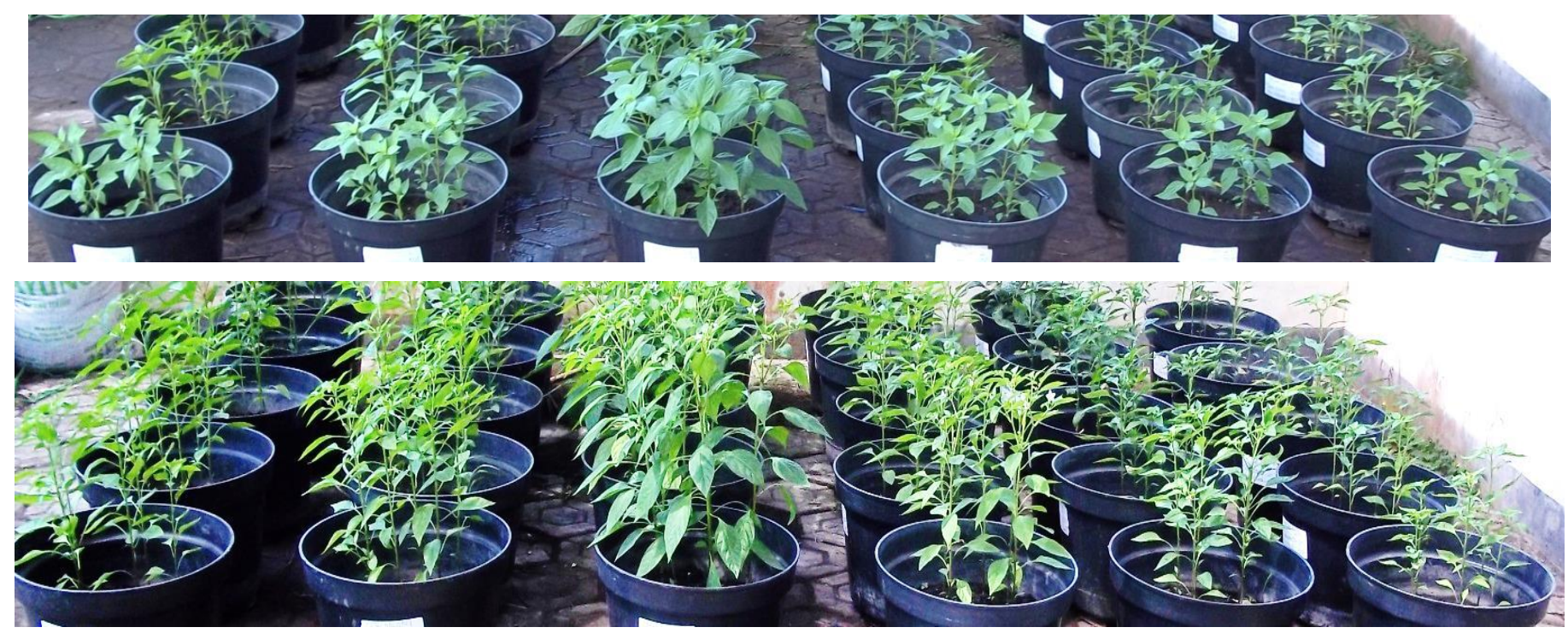

Figure ${ }_{5}$ Chilli of the Ceplik variety, grown with different compositions of Bromo volcanic ash (from left to the right control-without addition of Bromo volcanic ash, addition of $20 \%, 33 \%, 50 \%, 67 \%$ and $80 \%$ of Bromo volcanic ash to soil ). An addition of Bromo volcanic ash greater than $50 \%$ inhibited the growth of chilli in its early stages of growth, with smaller leaf areas per plant, and stunted growth overall.

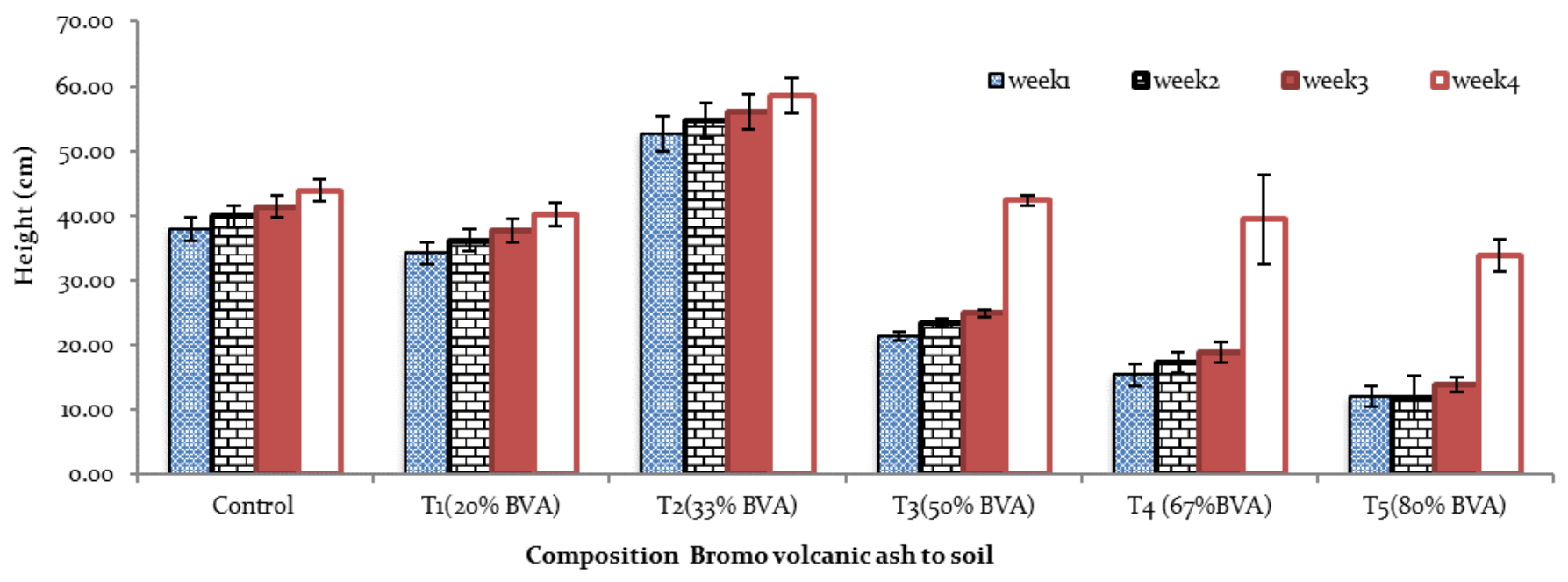

Figure 6 The height of chilli grown in different composition of soil and Bromo volcanic ash (control, 20\% BVA, 33\% BVA, 50\% BVA, 67 \% BVA and 8o\% BVA, during week 1 to week 4 (9 weeks old to 12 weeks old after planting) 


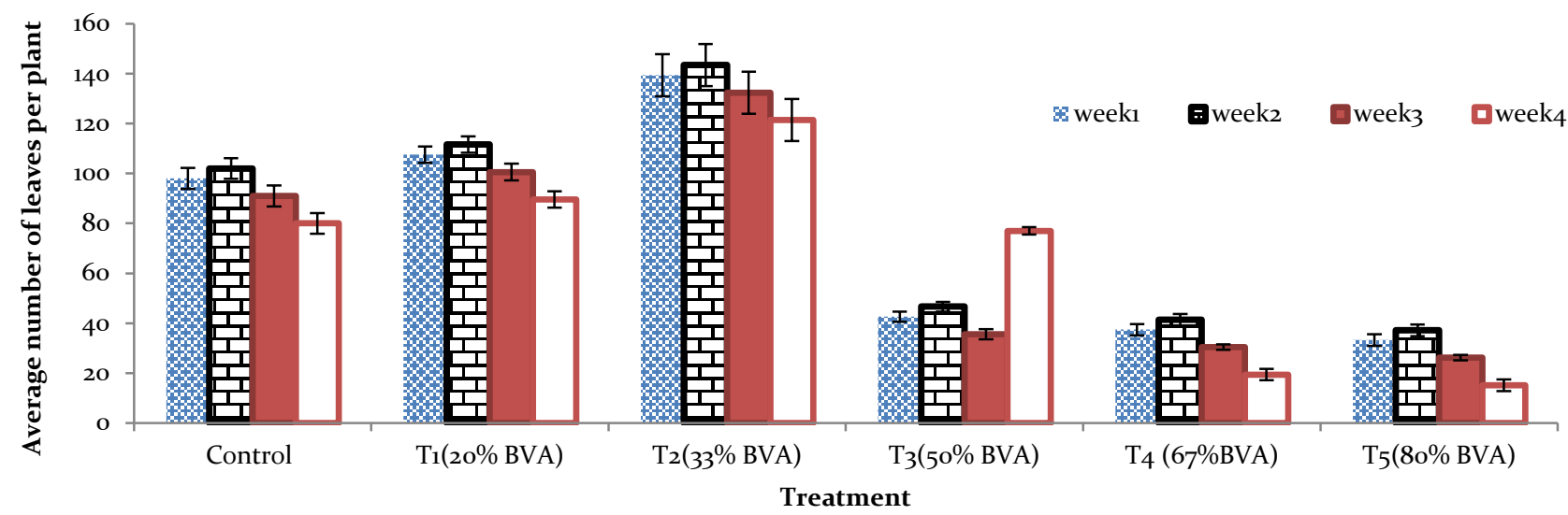

Figure 7 Average number of leaves per plant of chilli grown in different levels of Bromo volcanic ash, control, $20 \%$ BVA, 33\% BVA, $50 \%$ BVA, 67\% BVA, and $80 \%$ BVA) during week -1 to week-4

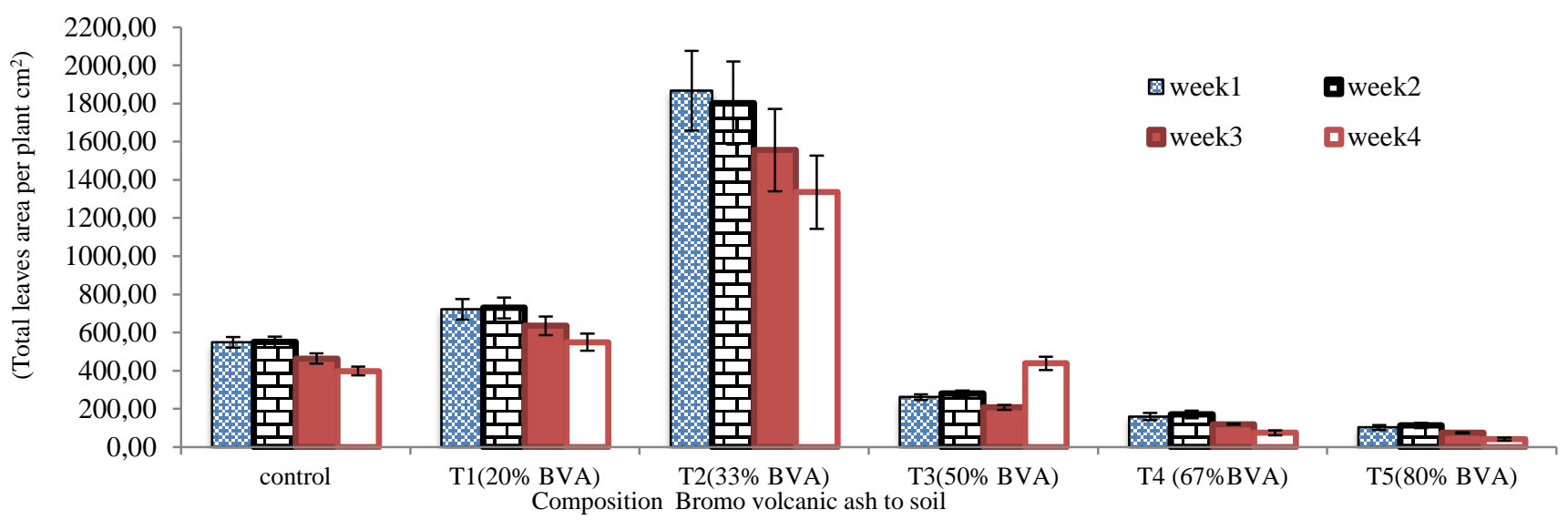

Figure 8 Total leaf area per plants of Chilli grown in different composition of soil and Bromo volcanic ash (control, 20\% BVA, 33\% BVA, 50\% BVA, 67\% BVA and $80 \%$ BVA) during week 1 to week 4

\subsection{Monitoring the growth of chilli by bioelectricity measurements}

The optimal growth of chilli had a mixture of Bromo volcanic ash of $33 \% \mathrm{BV}$ ash and $67 \%$ soil. This ratio showed a higher value of PD (Figure. 9, Table 1). From the bioelectricity measurements, (Figure 9) it can be seen that the largest leaf surface electric potential, provided the optimal growth for the Ceplik Chilli variety (Figure 10, Figure 8). It appeared that the chilli had grown optimally in BV ash. Here the addition of BV ash to the soil increased the PD of the leaves in ranges up to $(-62.50$ to -80.00$)$ $\mathrm{mV}$; (-90 to-178.33) mV; (-146.67 to-295.00) mV; (-90.00 to- 100) $\mathrm{mV}$; (-6o to- 65) $\mathrm{mV}$ and (-25 to-3o) $\mathrm{mV}$, each from controls, 1,2,3,4 and 5 treatment plants, respectively.

The biggest value of electrical PD showed the best performance of the chilli in photosynthesis. The electrical PD of leaves increased during measurements taken from week-1 to week-3 (9 weeks old to 11 weeks old) and slightly reduced, thereafter, as the plants were in the maturity stages.
The electrical PD results included additional parameters of total leaf area (Figure 8), height of plant (Figure 6), the number of leaves (Figure 7) and yield (Figure 10). The measurements and visual observations (Figure 5 to Figure 10), have shown that a composition of one thirds of Bromo Volcanic Ash (33\%) to soil gave the best results in chilli growth and yield.

Yellow colorization symptoms were observed on the plant leaves during fruiting (Figure 12) that might have occurred during the chilli's photosynthesis. Photosynthesis involves the absorption of $\mathrm{Mg}$ and $\mathrm{Fe}$. The effect of $\mathrm{Mg}$ on the photosynthetic process can be observed by shifting the potential difference (Figure 9). It is possible to measure by using an electrometer with high impedance, at around $10^{10} \mathrm{ohm}[22,23]$. The yellowing or chlorosis might be a stress symptom of $\mathrm{Pb}$ exposure. Longer and higher exposure to $\mathrm{Pb}$ may cause widespread symptoms [24]. It might also be from an imbalance of nutrients such as $\mathrm{Mg}, \mathrm{K}$, Ca or from an increase of Fe concentration on the roots [25]. 
Table 1 Electrical Potential Difference (PD) and standard error (S. e.) of chilli grown in different soil concentrations of Bromo volcanic ash (BVA) from the 2010 eruption.

\begin{tabular}{|c|c|c|c|c|c|c|}
\hline \multirow[b]{2}{*}{ Week of measurement } & \multicolumn{6}{|c|}{$\mathrm{PD} \pm \mathrm{se}(\mathrm{mV})$} \\
\hline & Control & T-1 20\% BVA & T-233\% BVA & $\mathrm{T}-3-50 \% \mathrm{BVA}$ & T-4-67\% BVA & T-5-80\% BVA \\
\hline Week-1 & $-80.00 \pm 0.00$ & $-100.00 \pm 0.00$ & $-146.67 \pm 11.55$ & $-90.00 \pm 0.00$ & $-60.00 \pm 0.00$ & $-30.00 \pm 0.00$ \\
\hline Week-2 & $-68.33 \pm 1.44$ & $-100.00 \pm 0.00$ & $-220.00 \pm 0.00$ & $-100.00 \pm 0.00$ & $-60.00 \pm 0.00$ & $-30.00 \pm 0.00$ \\
\hline Week-3 & $-78.33 \pm 2.89$ & $-178.33 \pm 2.89$ & $-295.00 \pm 8.66$ & $-100.00 \pm 0.00$ & $-60.00 \pm 0.00$ & $-25.00 \pm 0.00$ \\
\hline Week-4 & $-62.50 \pm 1.44$ & $-90.00 \pm 0.00$ & $-233.33 \pm 5.77$ & $-90.00 \pm 0.00$ & $-65.00 \pm 0.00$ & $-30.00 \pm 0.00$ \\
\hline
\end{tabular}

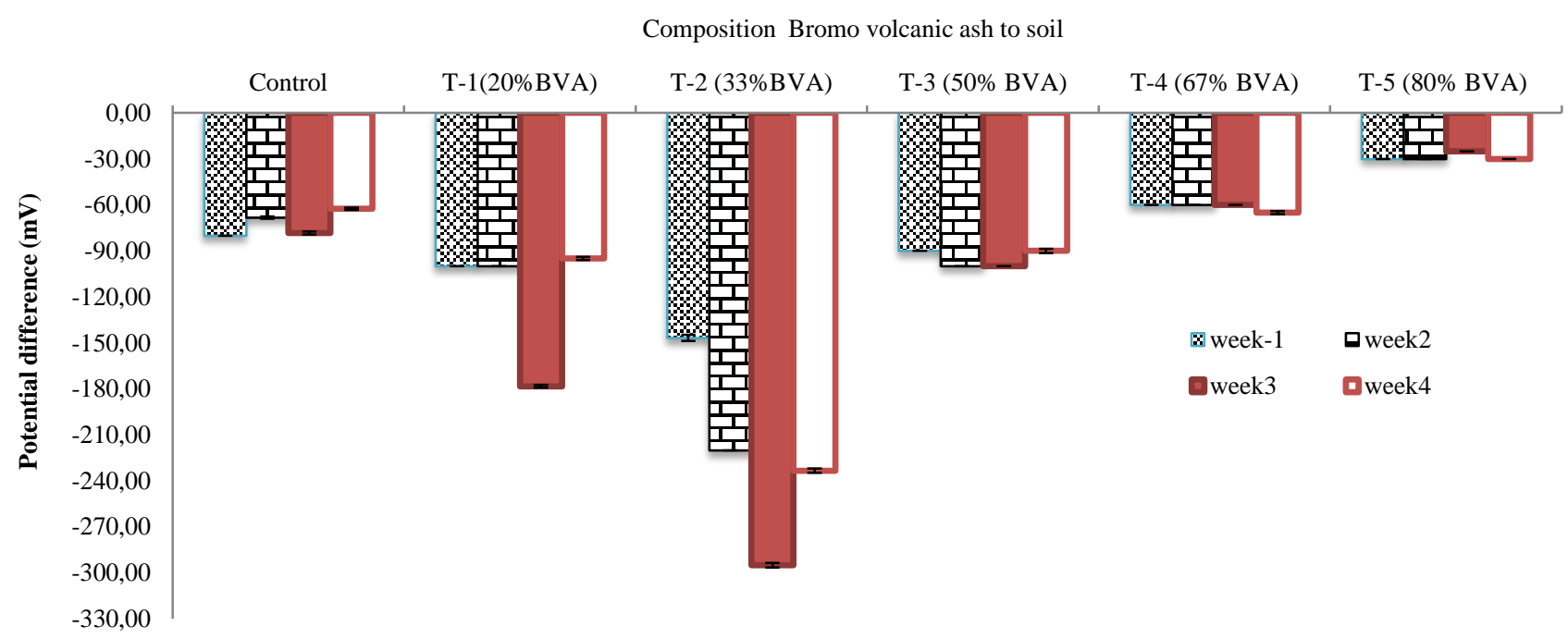

Figure 9 The electrical leaf surface potential difference (PD) of chilli variety, Ceplik grown in different concentrations of Bromo volcanic ash (BVA) to soil. Week-1 to week-4 experiment.

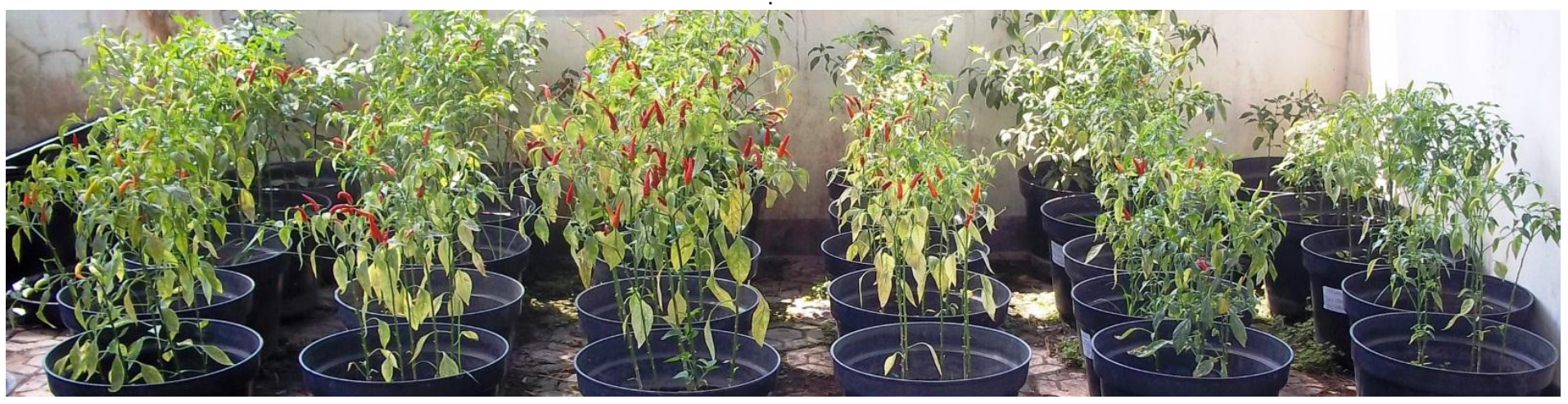

Figure 1o Chilli variety of Ceplik grown with different additions of Bromo volcanic ash (from left to right, control-without addition of Bromo volcanic ash, addition of $20 \%, 33 \%, 50 \%, 67 \%$ and $80 \%$ of Bromo volcanic ash to soil ). Addition of $50 \%$ Bromo volcanic ash to soil had lower chilli production, late flowering, late fruiting and late ripening. An Addition of $30 \%$ of Bromo volcanic ash to the soil had the largest production of chilli. 


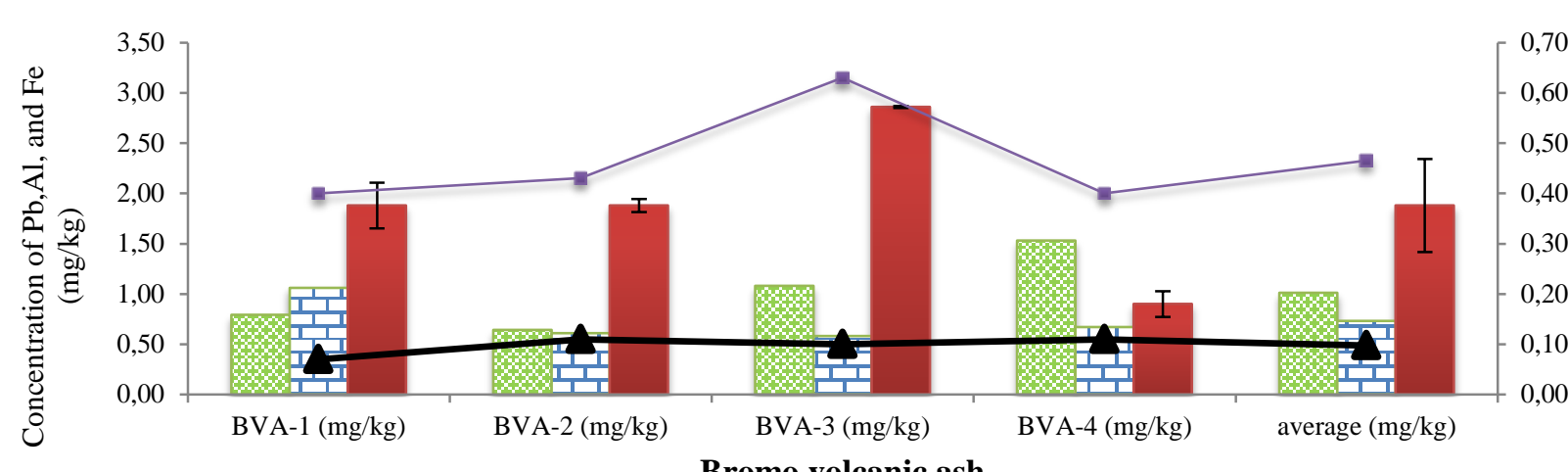

Bromo volcanic ash

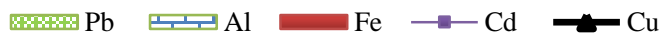

Figure 11 Lead $(\mathrm{Pb})$, Aluminum (Al), Iron ( $\mathrm{Fe})$; Cadmium $(\mathrm{Cd})$ and Copper $(\mathrm{Cu})$ content of Bromo volcanic ash (BVA) from four different position samples taken from the center of eruption (Figure 6). The composition of $\mathrm{Pb}, \mathrm{Cd}, \mathrm{Cu}, \mathrm{Al}$ and $\mathrm{Fe}$ on the area did not exceed the threshold of permissible levels on the soil.

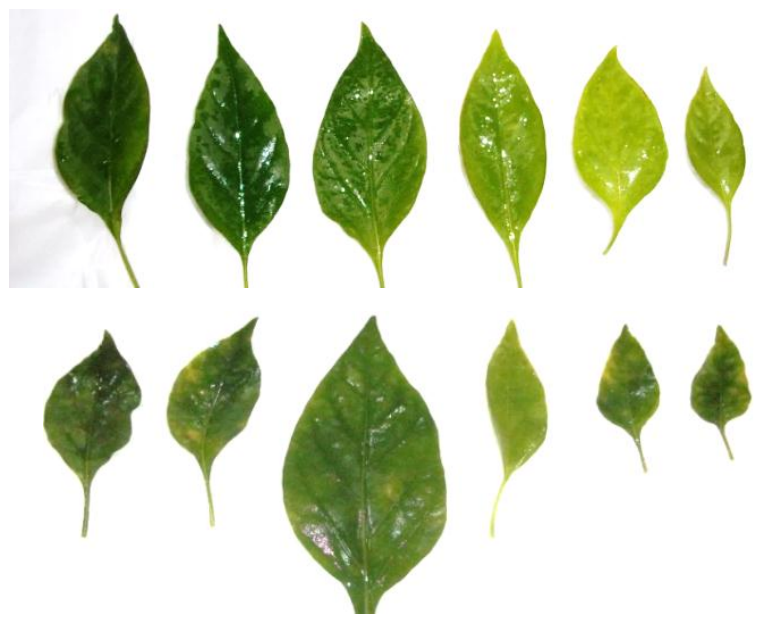

Figure 12 Yellow spots appeared on the leaves during the 3 rd week of measurements (lower). No yellow spots were present during the first week of measurements.

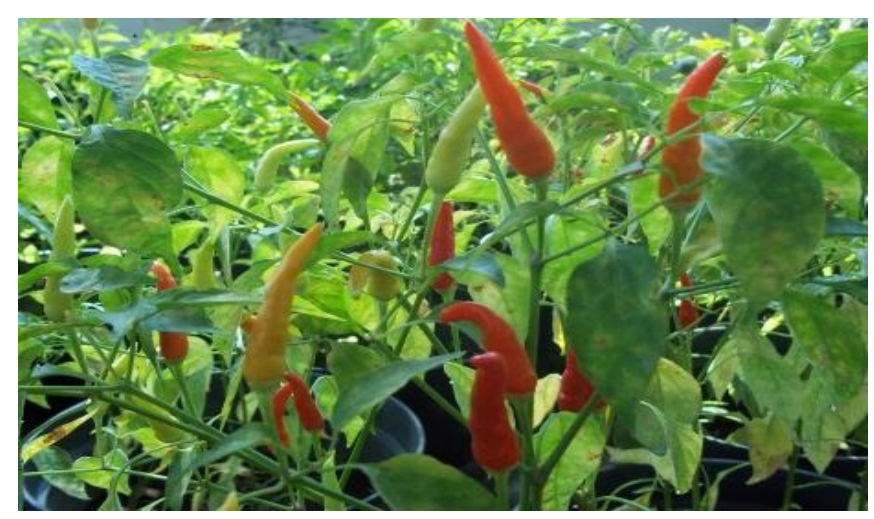

Figure 13 Fruit of the Ceplik chilli variety

\subsection{Heavy Metal Content of Bromo volcanic ash}

During eruptions, millions of tons of ash particles were blasted hundreds of kilometres away. It seemed that different locations had different $\mathrm{Pb}$ and $\mathrm{Cd}$ contents, ranging between $0.64-1.53$ $\mathrm{mg} / \mathrm{kg}$ and $0.40-0.63 \mathrm{mg} / \mathrm{kg}$ each, or an average of (1.01 \pm 0.23 ) $\mathrm{mg} / \mathrm{kg}$ and (0.47 0.06 ) $\mathrm{mg} / \mathrm{kg}$ (Figure 11). $0.3 \mathrm{mg} / \mathrm{kg}$ and 0.2 $\mathrm{mg} / \mathrm{kg}$, was a permissible content level on a leafy plant, while the levels for a fruiting vegetable was $0.1 \mathrm{mg} / \mathrm{kg}$ and $0.1 \mathrm{mg} / \mathrm{kg}$, each for $\mathrm{Pb}$ and $\mathrm{Cd}[26]$. Cadmium is classified as carcinogenic to humans. An increase of $\mathrm{Cd}$ in soil increases the uptake of $\mathrm{Cd}$ in plants. From heavy metal measurements, it can be seen that BV ash in the four location points noted by sample 1 to sample 4 , had not exceeded the threshold level of lead in soil. The threshold level is $20 \mathrm{mg} / \mathrm{kg}$, and for $\mathrm{Cd}$, that ranged between $0.43 \mathrm{ppm}-0.63$ ppm. It had also not exceeded the threshold levels of $1 \mathrm{ppm}$, and $\mathrm{Cu}$ at $20 \mathrm{ppm}$ [26]. We have yet to measure the heavy metal contents of the chilli fruit. The plant needs $\mathrm{Cu}$ in small amounts. The plant also needs Fe for photosynthesis.

Bromo volcanic ash also contained different levels of $\mathrm{Cu}, \mathrm{Al}$, and Fe between the locations of the samples (Figure 11), ranging from $0.07 \mathrm{mg} / \mathrm{kg}$ to $0.11 \mathrm{mg} / \mathrm{kg}$; $0.58 \mathrm{mg} / \mathrm{kg}$ to $1.06 \mathrm{mg} / \mathrm{kg}$; and 0.9 $\mathrm{mg} / \mathrm{kg}$ to $2.86 \mathrm{mg} / \mathrm{kg}$, or an average of (o.10 \pm 0.01$) \mathrm{mg} / \mathrm{kg}$, $(0.73 \pm 0.13) \mathrm{mg} / \mathrm{kg}$, and $(1.88 \pm 0.46 \mathrm{mg} / \mathrm{kg})$, respectively. The value of $\mathrm{Cu}$ and Fe were smaller compared to the Eyjafjallajökull volcano's concentrations of $20.77 \mu \mathrm{g} / \mathrm{g}$ of $\mathrm{Cu}$ and $6.09 \mathrm{mg} / \mathrm{g}$ of iron $6.09 \mathrm{mg} / \mathrm{g}(\mathrm{Fe})[7]$. Also, the concentration of $\mathrm{Pb}$ and $\mathrm{Cd}$ of Bromo volcanic ash $(1.01 \mu \mathrm{g} / \mathrm{g}$ of $\mathrm{Pb}, 0.47 \mu \mathrm{g} / \mathrm{g}$ of $\mathrm{Cd})$ were smaller than the Eyjafjallajökull volcano of $54.9 \mu \mathrm{g} / \mathrm{g}(\mathrm{Pb})$, and $3.419 \mu \mathrm{g} / \mathrm{g}(\mathrm{Cd})$ [7]. According to [27], Bromo ash contained $\mathrm{SiO}_{2}, \mathrm{Al}_{2} \mathrm{O}_{3}, \mathrm{Fe}_{2} \mathrm{O}_{3}$, $\mathrm{Ca}, \mathrm{K}, \mathrm{Mn}, \mathrm{Cu}, \mathrm{Ag}, \mathrm{Ba}, \mathrm{Zn}, \mathrm{Pb}$ and other substances in different compositions. Volcanic ash consisted of $\mathrm{Si}, \mathrm{Al}, \mathrm{K}, \mathrm{Na}, \mathrm{Ca}, \mathrm{Mg}, \mathrm{Fe}$ and may be different among other volcanic ash samples, depending upon the magma composition [28]. 


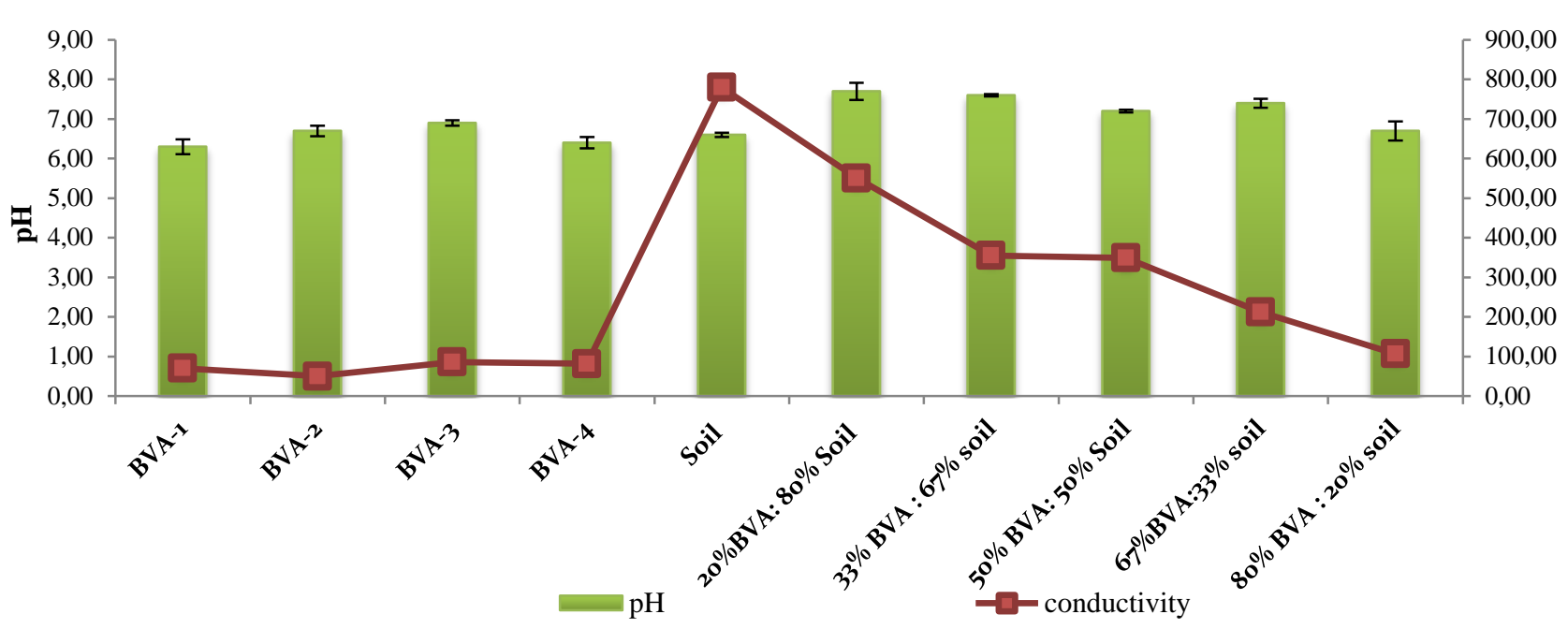

Figure 14 The $\mathrm{pH}$ and conductivity of four different location points on the area where the ash samples of the 2010 Bromo eruption were taken (Bromo volcanic ash-BVA-1, BVA-2, BVA-3, and BVA-4); soil (used from growth media) and treatments (20\% BVA; 33\% BVA; 50\% BVA; 67\% BVA and 80\% BVA addition to soil)

\subsection{Resilience, sustainability and the implication for practical application}

The eruption of Bromo was considered to be one of the biggest eruptions that had not only affected the area surrounding the mountain, but had also affected distant areas. Agricultural products in the immediate area such as chilli were affected and caused a decrease in supply. Probolinggo, a central hub for chilli, wasn't able to supply Banyumas sellers in central Java, causing its price to exceed IDR 9oooo, or around 8 to 9 times its normal price [5]. In Cemoro Lawang-Ngadisari-Sukopura, a sub district of the Probolinggo district, around 30 ha of agricultural land was damaged. This land was mostly for harvesting cabbage, potatoes and spring onions. In Malang, Ngadas, a village $15 \mathrm{~km}$ from the centre of Bromo, and in Poncokusumo village, 6 ha of 120 ha of potato crops were damaged. The government contributed around 10 tons of potato seeds and 2.5 tons of liquid fertilizer in agricultural aid [29, 30]. Many farmers started their work as soon as possible, often before the volcanic activity had subsided fully due to the length of the incident and their budget limitations. In the Pasuruan district, volcanic ash had covered maize, rice and grass to feed livestock that eventually caused the death of cattle [17]. The volcanic ash had caused damage to around 132 ha of agricultural land [18], including 43 ha of potatoes, 50 ha cabbage, 39 ha of Chinese cabbage, and to smaller numbers of onion crops, within Argosari village. In the village of Tosari, around 70 hectares of potato crops were subjected to varying degrees of damage, with a loss of approximately IDR 2.5 billion. IDR 1 billion, were being severely damaged.

Two years after the 2010 Bromo eruption, the food security (availability) in Ngadirejo village was still low [18]. Besides a shortage of food production and income, road damage also put around $40 \%$ of people in a vulnerable situation. In the Ngadirejo area (samples source), most people who planted potatoes; has difficult crop to cultivate, following an eruption. Chilli was mostly planted outside of the Ngadirejo area, as an alternative commodity product. Planting chilli in the Ngadirejo area, by reducing the concentration of BVA below $50 \%$, sustained the growth rate of the chilli.

The lessons learned from other eruptions might be used to enhance the people's adaptability. The increasing concentration of volcanic ash after the Merapi eruption of October 2010 had reduced the Sengon seedlings (Falcataria moluccana) growth [34]. After the eruption of Mt Pinatubo in 1991[14], many adversely affected farmland areas were unsuitable for agriculture. This caused a disruption of the production of agriculture-based industries. The prediction of a threat continued until the year 2010. Experiments on the volcanic material showed that rice still thrived in the chemical and physical deficiencies of volcanic materials in Mount Pinatubo, with the application of nitrogen fertilizer [35]. The volcanic eruption of Mt. St. Helens, deposited a maximum of $300 \mathrm{Mg} \mathrm{ha}^{-1}$ on agricultural crops [36]. Dust particles deposited on cotton leaves reduced dry weight, thereby altering plant physiology, with a reduction in photosynthesis and an increase in respiration [37].

From the impact of the Bromo eruption, it appeared that sudden climate change may drive farmers into a more vulnerable position, pushing people to their limits. Intervention is needed to sustain development. Integration of a strategy to strengthen resilience is utterly needed for developing countries with frequent volcanic eruptions and heavy budget constraints.

Planting hot chilli could help farmers earn better incomes. Ceplik chilli, in particular, can be harvested 3 times before being renewed. Ceplik chilli (Figure 13) was less labor-intensive than the big, red chillies, thus ensuring a better production.

Our results also showed that chilli may be adapted to a media with a mixture of soil and $\mathrm{BV}$ ash on $\mathrm{pH}$ ranges of 6.7 to 7.7 (Figure 14). As seen, the $\mathrm{pH}$ values of $\mathrm{BV}$ ash ranged between 6.3 to 6.9, with an average of $6.58 \pm 0.16$; similar to a soil $\mathrm{pH}$ of $6.6 \pm 0.06$.

$\mathrm{BV}$ ash has conductivity between $(50.33 \pm 0.13) \mu \mathrm{S} / \mathrm{cm}$ to $(86.00$ $\pm 0.07) \mu \mathrm{S} / \mathrm{cm}$, with an average of $(72.08 \pm 9.20) \mu \mathrm{S} / \mathrm{cm}$. While the conductivity of soil was around $(780 \pm 1.20) \mu \mathrm{S} / \mathrm{cm}$. Increasing BV ash over $50 \%$, decreased electrical conductivity to as low as 107 $\mu \mathrm{S} / \mathrm{cm}$ may affect yield quality of the chilli [31], for additions of $80 \%$ BVA).

Electrical conductivity is related to the holding capacity of the soil that could be used as an indicator of productivity. However, the greater conductivity such as in $20 \%$ BVA, $100 \%$ of soil, were not optimal for the growth of chilli. Thirty-three precents BVA was optimal for productivity. This might be unique to BVA, such as in the retention capacity and in the ability to fix elements [32]. An increase of BVA could lower nutrition and micro nutrients. 
Increased $\mathrm{pH}$ due to BVA did not have a large impact since chilli grows within a $\mathrm{pH}$ range of between 6 to 7 .

Aluminium content may be toxic [7], but here the BVA aluminium content (Figure 11) was lower than the permissible level. In the absence of the heavy metals, farmers might adapt by growing chilli, to increase their resilience and to create more income. Helpful farming practice tactics to mitigate harmful effects of ash fallout might be achieved by planting crops in soil with a composition of $1 / 3$ of ash, or at least in soil with a composition of under $50 \%$ of ash. Another economical solution involves removing ash and creating supplemental products such as cement [33, 34].

An increase of volcanic ash of more than $50 \%$ in the soil tends to inhibit chilli growth, while an addition of around $30 \%$ of volcanic ash increases the chilli plant's optimal growth. We discovered a viable method to increase the resilience of farmers and to protect their economic security from the Bromo eruptions onward. Further research is needed to determine whether or not chilli is toxic and to reduce the risk of heavy metal poisoning from elements such as $\mathrm{Pb}$ and $\mathrm{Cd}$.

Volcanoes often have heavy metals, such as $\mathrm{Cd}, \mathrm{Cr}, \mathrm{Hg}, \mathrm{Pb}$, and $\mathrm{Zn}$, [6] and consequently adversely affect health [8]. Thus, we should be more aware. Even though the concentration of $\mathrm{Pb}, \mathrm{Cd}$, $\mathrm{Cu}, \mathrm{Al}$ and $\mathrm{Fe}$ from the 2010 Bromo volcanic eruption was below permissible levels, further research is needed about the adaptation of a plant that might also be suitable for phytoremediation of soil. In order to reduce the risk of heavy metal contamination to humans, we must first understand the effect of those metals on plants. Continual monitoring of soil is needed to investigate the environmental effects of frequent eruptions [11].

The locals resumed agricultural activity as soon as the conditions had just begun to recede. Most of them, who couldn't afford to take time off, had no other choices. Efforts to ensure sustainability would help to build resilience. Ensuring the soil's growth capability may increase farmers' resilience during sudden climatic changes involving volcanic eruptions. Not only should this ensure farmers' productivity, but it should also protect environmental sustainability. Both may benefit the environment and reduce the risks for the people.

The disruptions caused by volcanic eruptions were high between the years $2010-2015$. The conditions continued for two years after the Bromo eruptions. We sought solutions to provide economic stability. We hoped that people would lose less and gain a greater understanding in a wiser culture with a higher resilience than its predecessor. More thoughts must be given to sustainability and more attention paid to where we are most vulnerable. By taking steps to build resilience and by adapting our systems to withstand such shocks we may keep moving forward.

It is evident that building resilience to sudden extreme climate change is essential to the sustainability of agricultural production. In order to reduce economic vulnerability that may lead to poverty, we must promote crop rotation by using commodity plants such as chilli that can support the local economy and secure production. Sustainability strategies can buttress the impact of sudden climate changes from volcanic eruption. This technique has effectively helped manage and reduce crop losses by implementing new agricultural practices in response to volcanic ash fallout. These results might be extended to other crops by using these innovative techniques for production.

\section{Conclusion}

The results showed that an increase of more than $50 \%$ of ash in the soil tended to inhibit the chilli plant's growth. Meanwhile, an increase of $33 \%$ of ash actually increased a chilli plant's optimal growth. This is a viable method to enhance resilience and to protect humans from the effects of BV ash. Further research is needed to evaluate the toxicity levels of chilli grown in volcanic ash to reduce the risk of heavy metal poisoning.

To increase resilience, volcanic ash must be reduced. As for the optimal growth of chilli, only $1 / 3$ of BVA is needed. The volcanic ash may be converted to other materials such cement. It may be possible to increase adaptability and resilience of people in the affected area of Bromo, and in other similar areas in Indonesia with frequent volcanic disturbances.

Building sudden, extreme climate resilience projects are essential to the sustainability of agricultural production to reduce vulnerability that may lead to social crises such as poverty. Promoting commodity replacement plants such as chilli can support the local economy and to secure production; a strategy for sustainability on the impact of sudden climate change due to volcanic eruption. This technique has effectively helped manage agricultural practices and thereby reduced crop loss from volcanic ash.

\section{Acknowledgements}

The author would like to thank Mr. Mohammad Syafii, the head of post-PVMKG (Pusat Vulkanologi Mitigasi Bencana- The Centre of Volcanology and disaster mitigation), for the informational interview by A Solihin on 17 May 2011, in post-monitoring PVMKG Bromo, the farmers who assisted in collecting ash, and $\mathrm{Mr}$. Mintadi, from the Department of Chemistry, who assisted in the heavy metal examinations.

\section{References}

[1] Robock A., Climatic Impact of volcanic emissions. In press. A Chapter of state of the Planet (AGU monograph, Steve Sparks and Chris Hawkesworth, Editors)2004:1-25.

[2] Robock A., Volcanic eruptions and climate, Reviews in geophysics 2000; 38 (2): 191-219

[3] Corradini, S, Tirelli, C., Gangale, G., Pugnaghi, S., Carboni, E., Theoretical Study on volcanic plume $\mathrm{SO}_{2}$ and ash retrievals using ground TIR camera: sensitivity analysis and retrieval procedure developments. IEEE transactions on geoscience and remote sensing 2010; 48(3): 1619-1628.

[4] Cole-Dai J. Volcanoes and climate. John Wiley \& Sons, Ltd. wires.wiley.com/climatechange 2010

[5] Pikiran Rakyat 6 January 2011. Bromo erupsi cabai rawit menghilnag. Pikiran Rakyat.com. Accessed 11 February 2011.

[6] Wilson T, Kayo G, Steward C, Cole J. Impacts of the 2006 eruption of Merapi Volcano Indonesia on agricultural and infrastructure 2007. GNS Science Report 2007/o7 6op.

[7] Nanzyo M. Unique properties of volcanic ash soils 2002: 99-112. Accessed on 6 May 2015.

[8] Shoji S. Volcanic ash soils: Genesis properties and utilization. Tokyo: Elsevier. 1993

[9] Shoji S, Takahashi T. Environmental and agricultural significance of volcanic soils. 2002:113 -135 .

[10] Cronin SJ, Sharp DS. Environmental impacts on health from continuous volcanic activity at Yasur (Tanna) and Ambrym Vanuatu. International Journal of Environmenta Health Research 2002; 12:109123.

[11] Noor J AE, Pujadi E. A survey of natural occurring radionuclides and particle concentrations from erupting Mount Bromo in East Java. Indonesia. International Journal of Basic $\mathcal{E}$ Applied Sciences IJBASIJENS. 2012; 12(3): 25-28. 
[12] Seaward MRD, Richardson DHS. Atmospheric sources of metal pollution and effects on vegetation. Chapter 6 . Heavy metal tolerance in plants: Evolutionary aspects. In Jonathan Shaw. 1989

[13] Ochota P, Prokopowicz A, Kośmider L, Choina M, Stebel A, Sobczack, A. Heavy metals in moss samples exposed to atmospheric dust after eruption of the Efjafjallajökull volcano. Enviromental Medicine 2012; 15(1): $21-26$

[14] Sudaryo, Sucipto. Identifikasi dan penentuan logam pada tanah vulkanik di daerah Cangkringan Kabupaten Sleman dengan metode analisis aktivasi Neutron cepat. Yogyakarta: STTN-Batan Yogyakarta, 2009.

[15] de Guzman EM. Eruption of Mount Pinatubo in the Philippines in June 1991. Asian disaster reduction centre. www.adrc.asia/publication/recovery_reports/pdf/Pinatubo.pdf. Accessed 9 September 2015

[16] Pemerintah Kabupaten Probolinggo. Gunung Bromo. http://www.probolinggikab.go.id/site/index.php?option=com_content \&task=view\&id= 922\&Itemid=1 Accessed 10 February 2011

[17] Kompas.com. Abu Bromo rusak 132 hektare lahan pertanian. Sigap bencana, Jumat 17 Desember 2010. Accessed 1o February 2011

[18] Kompas.com Tanaman kentang rusak akibat abu vulkanik Bromo (Selasa 28 Desember 2010).Accessed 10 February 2011..

[19] IPCC, 2007. Climate change 2007: Impacts, adaptation and vulnerability. Contribution of working group II to Fourth Assessment Report of the Intergovernmental Panel on Climate Change, ML. Parry, OF Canziani, JP. Palutikof PJ. Van der Linden and CE Hanson, eds. Cambridge University Press, Cambridge, UK.976.

[20] Mitchell T, Harris K. Resilience: A risk management approach. Background note 2012. Overseas Development Institute. http://www.odi.org/sites/odi.org.uk/files/odi-assets/publicationsopinion-files/7552.pdf

[21] IPCC 2012. Managing the risk of extreme events and disasters to advance climate change adaptation. A special report of working group I and II of the intergovernmental panel on climate change. Field $\mathrm{CB}$, Barros V, Stocker TF, Qin D, Dokken DJ, Ebi KL, .Mastrandrea MD,.Mach KJ, Plattner GK,.Allen SK, Tignor M, Midgley PM, eds.Cambridge University Press. New York.

[22] Hariadi Y, Shabala S. Screening broad bean (Viciafaba) for magnesium deficiency.II Photosynthetic performance and leaf bioelectrical responses. Functional Plant Biology 2004a; 31: 539-549.

[23] Hariadi Y, Shabala S. Screening Broad Bean (Viciafaba) for Magnesium deficiency I. Visual deficiency symptoms and plant nutrition status. Australia: Functional Plant Biology 200 4b; 31(5): 529-537.

[24] Nurhayati AY., Hariadi YC., Lestari P. Early detection of lead stress on Marsilea crenata using bioelectricity measurement. Procedia Environmental Sciences 2015; 28: 57-66.

[25] Kopittke P., Asher C., Kopittke R \& Menzies N. Toxic effects of on growth of Cowpea (Vigna unguiculata). Australis: School of Land and Food Sciences and CRC for contamination and remediation of the environment. Enviromental Pollution 2007; .150:280-287.

[26] FAO/WHO Codex Alimentarius Commision. Joint FAO/WHO standards programme Codex Commitee on contaminants in Food. The Hague, The Netherlands, 21-25 March 2011. Working Document for information and use in disscussions related to contaminants and Toxuns in the GSCTFF. Plant Soil 2013; 362: 319-334.

[27] Moldoveanu AM. Assessment of soil pollution with heavy metals in Romania. INTECH. 2014; 284-305 Chapter 9. Cdn.intechopen.com/pdfwm/46338.pdf. Accessed 16th September 2015.

[28] Bayuaji R, Darmawan, MS, Pudji IR, Husin N. A. Characterization of pozzolanicity Bromo's volcanic ash. Proceedings of International Seminar on Applied Technology, Science, and Arts (3 ${ }^{\text {rd }}$ APTECS) Surabaya, 2011.ISSN 2086-1931.

[29] Media Indonesia, 5 January 2011. Pemkab Malang ganti tanaman rusak akibat abu Bromo, Accessed on 10 February 2011.

[30] Tempo, interaktif, Senin, 2oDesember 2010. Abu Bromo Rusak Tanaman Sayuran. Accessed 1o February 2011.

[31] Tadesse T, Nichols MA, Fisher KJ. Nutrient Conductivity Effect on Sweet Pepper Plants Grown using A Nutrient Film Technique. Yield and Fruit Quality. New Zealand Journal of Crop and Horticultural Science 1999; 27: 229-237.
[32] Ibrahiem EM, Ahmed SA. Evaluation of Jebel Marra volcanic ash as supplementary cementitius material for use in blended cement. IOSR Journal of Engineering (IOSRJEN) 2014; 4(3): 31-37

[33] Nurrohmah SH, Wahyudi A, Baskorowati L. Pengaruh abuvulkanik pada pertumbuhan, luas, serangan dan intensities serangan karat tumor pada semai Sengon. Jurnal Pemuliaan Tanaman Hutan, 2014; 8(2): 93-107

[34] Yeyes RY, Neue HU. Characterization of the volcanic ejecta from Mount Pinatubo and its impact on rice production .Philipp J crop Sci.1991, 16(2): 69-73

[35] Cook RJ., Baron JC., Papendick RI., and William GJ.III. Impact on agriculture of the Mt St Helens eruptions Science (Washington, DC):1980; 211: 16-22.

[36] Armbrust, DV. Effect of particulates (dust) on Cotton growth, photosynthesis, and respiration. Agron J.1986; 76: 1078-1081.

[37] Rahmawati W, Erliana UD, Habibie IY, Harti LB. Ketahanan pangan keluarga balita pasca letusan gunung Bromo, Kabupaten Probolinggo, Indonesia.Indonesian Journal of Human Nutrition. 2014; 1(1): 35-49. Ijhn.ub.ac.id/index.php/ijhn/article/view/99. Accessed 17 September 2015. 